\title{
FACTORS AFFECTING THE COMPETITIVENESS OF A HIGHER EDUCATION INSTITUTION: SYSTEMATIC LITERATURE OVERVIEW
}

\author{
Liāna Supe, Artūrs Zeps, Ingūna Jurgelāne, Leonīds Ribickis \\ Riga Technical University, Latvia \\ Liana.Supe@rtu.lv; Arturs.Zeps@rtu.lv; Inguna.Jurgelane@rtu.lv; Leonids.Ribickis@rtu.lv
}

\begin{abstract}
The aim of the study is using systematic literature analysis method - literature overview - identify the factors, which affect the competitiveness of a higher education institution in the conditions of globalization. Qualitative methods, as well as systematic literature analysis method - literature overview have been used in the study. More than 6000 scientific articles were considered to choose 20 full text articles for in-depth analysis. Main conclusions and results - the systematic literature analysis method - literature overview is a convenient tool for systematizing, selecting and collecting information about the research subject, using author's articles, which have already gathered key information from a number of researchers of a specific topic together; the competitiveness of higher education institution is influenced by the internal factors that are formed by the internal environment of the higher education institution and external factors that are formed by the external micro-environment and macro-environment influenced by the state policy; an analysis of the internal and external factors of an institution is important in order to create competitive advantages in a higher education institution.
\end{abstract}

Key words: higher education institution, competitiveness, competitiveness factors.

\section{Introduction}

The competitiveness of higher education institution is a widely researched topic and this is very important in strategic management of higher education institution, identifying competitive advantages and creating new ones. Furthermore, the role of competitiveness of higher education institution is increasing according to changes in higher education sector overall - world-class universities, the USA phenomenon, classification in research universities and universities of applied sciences, the increasing influence of stakeholders, etc. Competitiveness can be defined as the ability of an organization to create and maintain competitive advantages (Dimitrova \& Dimitrova, 2017). One more significant aspect in creation and identification of competitive advantage is determination of factors affecting the competitiveness of a higher education institution. Factor analysis is required in order to determine the variety of factors and classification possibilities. Competitiveness of a higher education institution characterizes its ability to meet the needs of internal and external stakeholders on the basis of available competitive advantages which are formed under the influence of set of internal and external conditions - competitiveness factors (Ashmarina, Khasaev, \& Plaksina, 2015).

The research question for this scientific research is - what factors influence competitiveness in a higher education institution? According to the study, the object of the study is the higher education institution and the subject of the research - factors influencing competitiveness. The aim of the study is using systematic literature analysis method literature overview - identify the factors, which affect the competitiveness of a higher education institution in the conditions of globalization. The following tasks have been defined to reach the aim - to conduct literature analysis about factors, which affect competitiveness of higher education institution, using the systematic literature analysis method overview; to collect and analyse the most relevant aspects about factors influencing competitiveness of higher education institution; determine the factors influencing competitiveness for a particular higher education institution; to summarize the results of the analysis and draw conclusions.

The most effective way to select and analyse high-quality and appropriate literature for the relevant research issue is the systematic literature analysis. It is possible to obtain the most relevant results of the research question during systematic analysis of the literature, as well as to select the appropriate literature, focusing directly on the research question.

As one of the tasks is to determine the factors influencing competitiveness for a particular higher education institution, Riga Technical University (RTU) is chosen for analysis. RTU is a modern internationally recognized university. It is the only polytechnic university in Latvia and the largest university in the country - it educates and trains almost 15 thousand students. RTU is constantly developing its infrastructure by constructing a campus on Kipssala Island. On completion, the campus will be the most advanced engineering study centre in the Baltic Region.

\section{Materials and Methods}

During the research, qualitative methods were used - monographic method, analysis and synthesis method, as well as systematic literature analysis method - literature overview. 
Applying overview method, more than 6000 scientific articles were considered to choose 20 fulltext articles for in-depth analysis using the method PRISMA Flow Diagram. Scientific articles were selected from databases EBSCO and Web of Science. For data synthesis a tabular method was used and information was displayed chronologically.

\section{Results and Discussion}

Systematic literature analysis method overview is based on a chronological, thematic, conceptual or other analysis of the literature review with an aim to summarize the most relevant and specific according to the research question. The process of writing a literature overview can be divided into five stages - the formulation of a research question, literature search, literature screening, synthesis and final analysis (Booth, Papaioannou, \& Sutton, 2012).

The research question for this scientific research was formulated using a three question method - who (who is the research question about?), what (what must the researcher find out to answer the research question?) and how (how will the study impact on the 'who'?), is - what factors influence competitiveness in a higher education institution? (Booth, Papaioannou, \& Sutton, 2012).

The next step is to search appropriate literature according to the research question. To select the most relevant literature, it is important to define the right key words. In this scientific article the following keywords were chosen - competitiveness, higher education institution, global competition, factors that affect competitiveness. Using defined key words, 5107 scientific articles were obtained in EBSCO database. During literature search process two key words were used on each search stage and the following results were obtained - competitiveness and higher education institution (3821 scientific articles); higher education institution and global competition (846 scientific articles); higher education institution and factors that affect competitiveness (440). Correspondingly, in the database of Web of Science, 1258,351 and 40 scientific articles were found.

The PRISMA flow diagram designed to help scientists /researchers improve the overview of systematic literature analysis, will be used to compile and select the most appropriate records (PRISMA Flow Diagram, 2018). The diagram is based on four steps - identification, screening, eligibility and inclusiveness. According to these steps, scientific articles will be selected and a selection of records will be conducted with the aim of reaching at least 20 sources corresponding to the research question - which factors influence competitiveness in higher education?

Figure 1 shows a flow diagram.

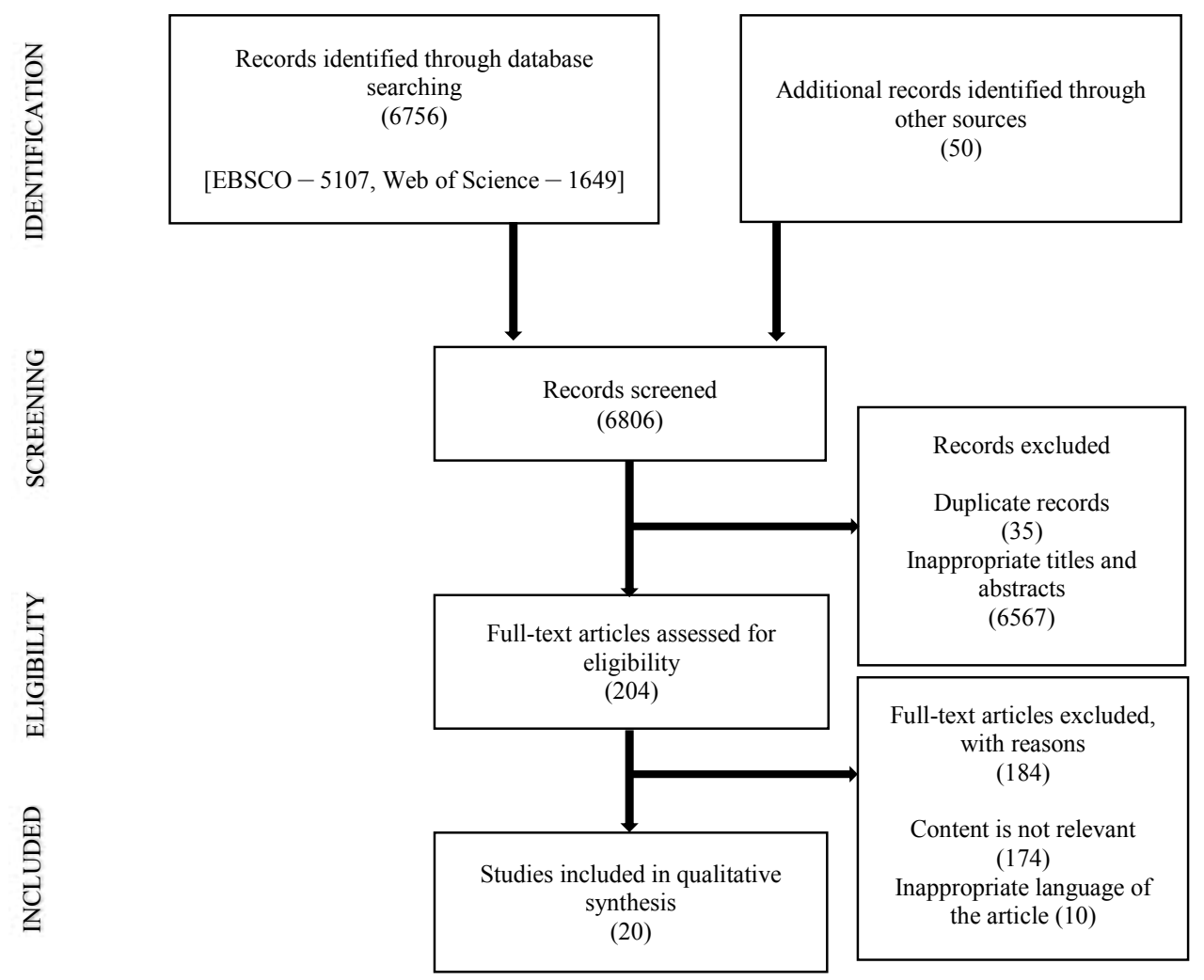

Figure 1. PRISMA literature search flow diagram (designed by the authors according to (PRISMA Flow Diagram, 2018). 
As a result, 20 entries were selected for inclusion in the literature overview. Scientific publications are mostly selected as well as some conference materials and paragraphs from books. The literature and source selection process is time-consuming, so defining and adjusting keywords in the selection process is important. Obtained results during literature search are summarized in Table 1.

According to applied systematic literature overview done in Table 1, in Table 2 is given an example of concrete University and factors affecting competitiveness of this higher education institution.
The core activities of RTU are teaching and learning, and continuous improvement in this field is also indicated in RTU Strategy. RTU provides prestigious, internationally recognised highquality studies that educate and train internationally competitive specialists who promote growth of the national economy of Latvia and are able to participate in lifelong learning. RTU evaluates student satisfaction on the basis of regular student surveys and annual self-assessment reports of study programmes in order to address the identified weaknesses and continuously improve the study process. RTU graduates have a

Table 1

Factors affecting the competitiveness of a higher education institution: results of systematic literature analysis method overview

\begin{tabular}{|c|c|c|c|}
\hline \multirow[t]{2}{*}{ No. } & \multicolumn{2}{|c|}{$\begin{array}{c}\text { Factors affecting the competitiveness of } \\
\text { a higher education institution (HEI) }\end{array}$} & \multirow[t]{2}{*}{ Relevance } \\
\hline & Group of factors & Factors & \\
\hline 1. & $\begin{array}{l}\text { Internal factors of } \\
\text { higher education } \\
\text { institution } \\
\text { competitiveness }\end{array}$ & $\begin{array}{l}\text { Personnel, } \\
\text { intellectual, } \\
\text { material, financial, } \\
\text { infrastructure } \\
\text { resources }\end{array}$ & $\begin{array}{l}\text { Theory of the resources and capabilities is relevant and useful in } \\
\text { analysis of internal environment. Innovations, market segmentation, } \\
\text { provided services, inimitability can be analyzed as internal capabilities. } \\
\text { VRIO model is aimed to internal factors analysis - value, rareness, } \\
\text { inimitability and organisation (Mainardes, Ferreira, \& Tontini, 2011). } \\
\text { Internal processes of HEI are classified in educational, research and } \\
\text { administrative processes and internal factors - personnel, intellectual, } \\
\text { material, financial, infrastructure (Ashmarina, Khasaev, \& Plaksina, } \\
\text { 2015). } \\
\text { Resource-based strategic approach, which is based on identification } \\
\text { of that kind of available resources and capabilities, which will be } \\
\text { important in long-term and will ensure long-term competitiveness } \\
\text { (Matkó \& Szücs, 2012). }\end{array}$ \\
\hline \multirow[t]{2}{*}{2.} & \multirow[t]{2}{*}{$\begin{array}{l}\text { External factors of } \\
\text { higher education } \\
\text { institution } \\
\text { competitiveness }\end{array}$} & $\begin{array}{l}\text { Macro environment } \\
\text { factors }\end{array}$ & $\begin{array}{l}\text { Macro environment factors are caused by the policy of the state, these } \\
\text { are social, scientific and technological, economic, political and legal. } \\
\text { To define and analyse macro environment factors of competitiveness, } \\
\text { different methods are applicable - } \\
\text { - Porters' five forces model. First force is entry of competitors, } \\
\text { second - bargaining power of buyers, third - bargaining power of } \\
\text { suppliers, fourth - rivalry among the existing players, fifth - threat } \\
\text { of substitutes. Sixth force - government's influence - is used in } \\
\text { Porters' model modification and this sixth force is important in } \\
\text { analyses of HEI (Mainardes, Ferreira, \& Tontini, 2011). } \\
\text { PEST analysis - political factors (how government political } \\
\text { decisions affect HEI), economical factors (how entrepreneurship } \\
\text { is organized and affects development of HEI), social (cultural } \\
\text { aspects, population, attitude to a career, level of education etc.) } \\
\text { and technological factors (research and development, technological } \\
\text { changes, innovations) (Matkó \& Szücs, 2012). }\end{array}$ \\
\hline & & $\begin{array}{l}\text { Microenvironment } \\
\text { factors }\end{array}$ & $\begin{array}{l}\text { Different kind of relationship analysis - with society, with companies, } \\
\text { with government, with potential students and power of students } \\
\text { (Mainardes, Ferreira, \& Tontini, 2011). } \\
\text { The microenvironment factors are caused by the activity of the } \\
\text { direct higher education institution environment - students, business } \\
\text { community, society etc. (Ashmarina, Khasaev, \& Plaksina, 2015). }\end{array}$ \\
\hline
\end{tabular}




\begin{tabular}{|c|c|c|}
\hline 3. & Other factors & $\begin{array}{l}\text { Factors influencing the competitiveness of higher education institutions: } \\
\text { the level of qualification of educational service providers; the image of } \\
\text { a higher education institution; satisfaction of key players in education } \\
\text { market services (Dimitrova \& Dimitrova, 2017). } \\
\text { International accreditation of study programmes; proportion of study } \\
\text { courses in English of whole study programme study courses; the role } \\
\text { of applied sciences universities in whole higher education system - } \\
\text { competitiveness factors (Komárek et al., 2017). } \\
\text { Virtual academic mobility as a competitiveness factor - improves the } \\
\text { competitiveness of University graduates (Absalyamova et al., 2017). } \\
\text { Competitiveness factors - quality of the input factors; financing; } \\
\text { utilization of the financial resources; appropriate level and quality } \\
\text { criteria of the education; internationality; technological development; } \\
\text { international recognition (Labas, Darabos, \& Nagy Tunde, 2016). } \\
\text { Knowledge management as a competitiveness factor (Nguyen, } \\
\text { Pattinson, \& Scott, 2016). } \\
\text { Striving for a world-level university - competitiveness factor (Chirikov, } \\
\text { 2016). } \\
\text { Globalization and valorisation - the drivers of competitiveness and the } \\
\text { factors affecting it (Bagley \& Portnoi, 2016). } \\
\text { An intercultural environment as a factor in improving the } \\
\text { competitiveness of higher education (Galkin et al., 2015). } \\
\text { Enterprise Resource Planning Systems as a factor affecting the } \\
\text { competitiveness of a higher education institution (Soliman \& Karia, } \\
\text { 2015). } \\
\text { Competitiveness of higher educational institutions depends on many } \\
\text { factors - an educational activity; research work; international activity; } \\
\text { financial and economic activity (Kobets \& Masych, 2015). }\end{array}$ \\
\hline
\end{tabular}

Table 2

Factors affecting the competitiveness of a higher education institution: Riga Technical University

\begin{tabular}{|c|c|c|}
\hline $\begin{array}{c}\text { Types of } \\
\text { competitiveness }\end{array}$ & $\begin{array}{c}\text { Factors of } \\
\text { competitiveness }\end{array}$ & Assessment indicators of competitiveness \\
\hline \multirow{3}{*}{$\begin{array}{l}\text { Competitiveness } \\
\text { of study process }\end{array}$} & $\begin{array}{l}\text { Experienced } \\
\text { teaching staff }\end{array}$ & $\begin{array}{l}\text { 1. The share of scientific and teaching employees having a Ph.D. and a Doctor } \\
\text { of Science degree, in the total amount of scientific and teaching employees. } \\
\text { 2. The share of full-time employees in the total amount of academic teaching } \\
\text { staff. } \\
\text { 3. Systematic upgrading of the academic staff competence. } \\
\text { 4. University annually attracts highly qualified foreign guest lecturers from } \\
\text { the European Union and beyond in order to strengthen the inclusion of } \\
\text { international knowledge into University study process }\end{array}$ \\
\hline & $\begin{array}{l}\text { Study process - } \\
\text { - developed } \\
\text { study process } \\
\text { - on traditional } \\
\text { academic } \\
\text { value-based } \\
\text { study process } \\
\text { - advanced } \\
\text { teaching } \\
\text { methods }\end{array}$ & $\begin{array}{l}\text { 1. University provides study programmes in } 12 \text { of } 29 \text { different study fields in } \\
\text { Latvia. } \\
\text { 2. Majority of the study programmes are in the STEM field. } \\
\text { 3. The number of students studying at University is stable; however, the } \\
\text { number of Latvian students drops every year. } \\
\text { 4. Growing number of international students. } \\
\text { 5. High percentage of alumni employment. } \\
\text { 6. Improved and revised study programs. } \\
\text { 7. The amount of additional education programs - life-long learning promotion. }\end{array}$ \\
\hline & $\begin{array}{l}\text { Innovation driven } \\
\text { teaching process }\end{array}$ & $\begin{array}{l}\text { 1. Introduced new interdisciplinary study courses for innovative product } \\
\text { development and entrepreneurship skills. } \\
\text { 2. University's Design Factory provides students the opportunity to create and } \\
\text { develop their projects using advanced prototyping devices and the latest } \\
\text { technologies. }\end{array}$ \\
\hline
\end{tabular}




\begin{tabular}{|c|c|c|}
\hline \multirow[t]{2}{*}{$\begin{array}{l}\text { Competitiveness } \\
\text { of study process }\end{array}$} & $\begin{array}{l}\text { Renewed } \\
\text { infrastructure } \\
\text { (premises and } \\
\text { equipment) }\end{array}$ & $\begin{array}{l}\text { 1. Infrastructure improvements to make the study environment more adapted } \\
\text { to the needs of a student-centred learning approach. } \\
\text { 2. Infrastructure improvements to ensure accessibility to the study facilities for } \\
\text { students with disabilities, thus creating an inclusive study environment. } \\
\text { 3. Reconstructed Scientific Library - common complex in the campus: new } \\
\text { service and opportunities for users; available to students twenty-four hours } \\
\text { a day, seven days a week, contributing to study accessibility. } \\
\text { 4. Open-access laboratories available for students. }\end{array}$ \\
\hline & $\begin{array}{l}\text { Well-designed } \\
\text { feedback system } \\
\text { (for students and } \\
\text { industry) }\end{array}$ & $\begin{array}{l}\text { 1. Student surveys and their feedback about the study process; regularly } \\
\text { revised student survey questions. } \\
\text { 2. Employer participation in the work of study field commissions. } \\
\text { 3. Employer satisfaction with the competence of graduates. }\end{array}$ \\
\hline \multirow{5}{*}{$\begin{array}{l}\text { Competitiveness } \\
\text { of research } \\
\text { process }\end{array}$} & $\begin{array}{l}\text { Experienced, } \\
\text { internationally } \\
\text { recognized } \\
\text { research staff }\end{array}$ & $\begin{array}{l}\text { 1. Increased selection requirements for professors to raise competitiveness } \\
\text { amongst the potential candidates. } \\
\text { 2. 3-year tenure track for professors. } \\
\text { 3. Support system for young researchers. } \\
\text { 4. Researchers attraction from abroad. }\end{array}$ \\
\hline & $\begin{array}{l}\text { Renewed } \\
\text { infrastructure } \\
\text { (premises and } \\
\text { equipment) }\end{array}$ & $\begin{array}{l}\text { 1. Student campus is concentrated and suitable for the modern research } \\
\text { process. } \\
\text { 2. All faculties have included short-term, medium-term and long-term } \\
\text { objectives and activities in their research programmes to provide better } \\
\text { research environment and infrastructure. }\end{array}$ \\
\hline & $\begin{array}{l}\text { Well-structured } \\
\text { research process }\end{array}$ & $\begin{array}{l}\text { 1. Research at University is organized in six inter-faculty research } \\
\text { fields or research platforms: Energy \& Environment; Information and } \\
\text { Communication Technologies; Materials, Processes \& Technologies; } \\
\text { Transport; Urban Development; Safety \& Security Technologies. } \\
\text { 2. University funding is distributed among the structural units on the basis of } \\
\text { research result quality and efficiency indices; the amount of the allocated } \\
\text { funding depends on the quality of publications. } \\
\text { 3. The Open Access Policy - to ensuring that all publications and research data } \\
\text { by University researchers are open, will provide the opportunity to achieve } \\
\text { better visibility of University researchers and develop networks. }\end{array}$ \\
\hline & $\begin{array}{l}\text { Study process } \\
\text { integrated in } \\
\text { research process }\end{array}$ & $\begin{array}{l}\text { 1. Student involvement in research activities and mobility programmes } \\
\text { (vertical integration). }\end{array}$ \\
\hline & $\begin{array}{l}\text { Research staff } \\
\text { renewal policy }\end{array}$ & $\begin{array}{l}\text { 1. The University Doctoral School is support mechanism for young researchers } \\
\text { within the Doctoral Studies Department to improve research environment } \\
\text { and quality of scientific work as well as to encourage interdisciplinary and } \\
\text { inter-institutional cooperation among doctoral students. } \\
\text { 2. University Research Excellency Grant for young scientists to ensure } \\
\text { that outstanding and promising young researchers are able to start their } \\
\text { researchers' career at University and develop their research in the direction } \\
\text { of a high and internationally important perspective. } \\
\text { 3. Post-docs are normally members of research project teams holding a } \\
\text { position of researcher or senior researcher. }\end{array}$ \\
\hline $\begin{array}{l}\text { Competitiveness } \\
\text { of valorisation } \\
\text { process }\end{array}$ & $\begin{array}{l}\text { Strong innovation } \\
\text { and valorisation } \\
\text { ecosystem }\end{array}$ & $\begin{array}{l}\text { 1. All faculties of the university take part in the valorisation process, which is } \\
\text { coordinated by the following units: } \\
\text { - Department of Business Development and Investments, which aims to } \\
\text { establish and sustain long-term relationships with business and social } \\
\text { partners, thus contributing to the increase in the number of contracts, } \\
\text { as well as to attract investments to University, projects and to lease } \\
\text { University real estate. } \\
\text { - Innovation and Technology Transfer Center }{ }_{2} \text { which aims at promoting } \\
\text { recognition of intellectual potential and innovation and technology } \\
\text { transfer at University. } \\
\text { Research Infrastructure and Technology Support Centre, which provides } \\
\text { access to University research infrastructure and resources (administrates } \\
\text { UseScience data base and High Performance Computing). }\end{array}$ \\
\hline
\end{tabular}




\begin{tabular}{|c|c|c|}
\hline \multirow{4}{*}{$\begin{array}{l}\text { Competitiveness } \\
\text { of valorisation } \\
\text { process }\end{array}$} & $\begin{array}{l}\text { Strong innovation } \\
\text { and valorisation } \\
\text { ecosystem }\end{array}$ & $\begin{array}{l}\text { - Design Factory offers support to University researchers, students and } \\
\text { staff in the fields of research, design, prototyping and education. } \\
\text { - Business incubators: student business incubator in University branch, } \\
\text { IdeaLab, and other. } \\
\text { 2. The total amount of innovative products of the university. }\end{array}$ \\
\hline & $\begin{array}{l}\text { Experienced } \\
\text { commercialization } \\
\text { personnel to } \\
\text { facilitated }\end{array}$ & $\begin{array}{l}\text { 1. University has structural units that give an opportunity to apply for business } \\
\text { incubators - finances, human resources and other assistance are provided to } \\
\text { students in order to successfully start their companies and create innovative } \\
\text { products and services. } \\
\text { 2. Involvement of students as well as academic and research staff in the } \\
\text { process of new product development. }\end{array}$ \\
\hline & $\begin{array}{l}\text { Well-developed } \\
\text { infrastructure } \\
\text { (premises and } \\
\text { equipment) }\end{array}$ & $\begin{array}{l}\text { 1. United study and research complex in Campus. } \\
\text { 2. Efficient technology transfer and innovation development environment to } \\
\text { promote creation of new technology businesses and products. }\end{array}$ \\
\hline & $\begin{array}{l}\text { Strong } \\
\text { collaboration with } \\
\text { industry }\end{array}$ & $\begin{array}{l}\text { 1. Well-developed collaborative networks fostering involvement in projects } \\
\text { and contract work. } \\
\text { 2. The amount of contracts/agreements to be made by R\&D. } \\
\text { 3. Research that is highly innovative and is investigating topics vital for the } \\
\text { society and national economy. } \\
\text { 4. Research programmes' activities provide commercial research services to } \\
\text { companies and governmental bodies and targeted commercialization of new } \\
\text { developments. } \\
\text { 5. Growing income from contracts with entrepreneurs and institutions. }\end{array}$ \\
\hline
\end{tabular}

stable and recognised status in the labour market. The quality of education provided by the RTU is greatly respected by both Employers' Confederation of Latvia, which unites leading enterprises in the industry, and foreign companies - CERN, Daimler AG, ESA and other, who employ RTU Doctoral students, research staff and alumni. The quality of RTU studies has been approved by international students as well. Due to a wide range of study programs implemented in English, in the last three years the number of international students at RTU has tripled, amounting to $11 \%$ from the total number of students. RTU has foreign students from all over the world - a total of 70 countries.

RTU conducts internationally competitive research and cooperates with reputable international research institutions, such as the European Organization for Nuclear Research CERN, European Space Agency, Royal Institute of Technology, Sweden, Fraunhofer Institute, Germany, and other.

RTU is the leader in research and innovation in the Baltic States. University research is an integral part of the study process. RTU Research Programme is a constituent part of RTU Development Strategy. Research at RTU is organized on six research platforms based on active and continuous analysis of market needs and commercial potential. The objective of research platforms is to ensure multifaculty and interdisciplinary research in the areas of great significance for the national economy and society.

Nowadays the role of a university is broader than before, since the outcomes expected from the society are not only linked to the academic and research capacity, but are also related to the third mission of higher education institution and its role in the society. RTU actively promotes technology transfer and innovation processes by supporting continuing education and is active in social engagement and interaction with the society.

RTU has declaimed valorisation - new product development and commercialization activities - as its third priority. Valorisation includes innovation, technology transfer and commercialization; therefore, special attention is paid to creation of new innovative technologies, their development and commercialization promoting establishment of new enterprises by students and members of academic personnel.

\section{Conclusions}

1. Systematic literature analysis method overview is a convenient tool for systematizing, selecting and compiling information about the research question using author's articles, which have already gathered key information from a number of researchers of a specific topic together.

2. In order to create competitive advantages for higher education institution, an analysis of the institution's internal and external factors is important.

3. The competitiveness of a higher education institution is influenced by internal factors, which are formed by the internal environment of a higher education institution - material, financial, 
personnel, infrastructure and other internal resources, and external factors formed by the external micro-environment (students, society as a whole) and the macro environment influenced by national policies (social, political, economic, legal, scientific and technical factors).

4. Analysing the macroeconomic factors PEST analysis can be used, which divides the macro environment into the political, economic, social and technological category, as well as there is a possibility to increase the number of categories by adding an analysis of cultural, environmental and other factors. This analysis method is used for strategic planning.
5. The Porter five-force model, which analyses the power of buyers and suppliers, threat of competitors, potential competitors and substitutes can be used to analyse external macro-environment, thus identifying existing positions and creating competitive advantages.

6. The VRIO model (value, rarity, imitability, organization) that describes the institution's internal resources and abilities can be used in internal factor analysis. This analysis shows how the existence of resources, competences and individuality makes a difference to one organization on the other, thereby creating a competitive advantage.

\section{References}

1. Absalyamova, S., Sakhapov, R., Absalyamov, T., \& Mukhametgalieva, C. (2017). Academic Mobility as a Factor of Improving the Competitiveness of University Graduates [Electronic version]. HELIX International Journal, Vol. 8(1), 2822-2827. DOI: 10.29042/2018-2822-2827.

2. Ashmarina, S.I., Khasaev, G.R., \& Plaksina, I.A. (2015). Methodological Basis of Higher Education Institution Competitiveness [Electronic version]. Review of European Studies, Vol. 7(2), 49-57. DOI: 10.5539/res.v7n2p49.

3. Bagley, S., \& Portnoi, L. (2016). Higher Education and the Discourse on Global Competition: Vernacular Approaches Within Higher Education Policy Documents [Electronic version]. Springer International Publishing. DOI: 10.1007/978-3-319-28191-9_2.

4. Booth, A., Papaioannou, D., \& Sutton, A. (2012). Systematic Approaches to a Successful Literature Review [Electronic version]. London: SAGE Publications Ltd.

5. Chirikov, I. (2016, June). How Global Competition is Changing Universities: Three Theoretical Perspectives [Electronic version]. Research and Occasional Paper Series, pp. 1-22.

6. Dimitrova, G., \& Dimitrova, T. (2017). Competitiveness of the Universities: Measurement Capabilities [Electronic version]. Trakia Journal of Sciences, Vol. 15(1), 311-316. DOI: 10.15547/tjs.2017.s.01.055.

7. Galkin, D., Pogukaeva, N., Ageeva, V.V., \& Nikolaeva, A. (2015). Intercultural Environment as a Competitive Advantage of Higher Education System [Electronic version]. Contemporary Educational Researches Journal, Vol. 05 (2), 55-61. DOI: 10.18844/cerj.v5i2.235.

8. Kobets, E., \& Masych, M. (2015). Higher Educational Institutions: Efficiency, Competitiveness, Rating [Electronic version]. Mediterranean Journal of Social Sciences, Vol. 6 (3), 269-273.

9. Komárek, J., Dočkal, J., Markovič, P., Březovská, B., \& Rigel, F. (2017). Higher Education for Higher Competitiveness [Electronic version]. Journal on Efficiency and Responsibility in Education and Science, Vol. 10 (2), 34-43. DOI: 10.7160/eriesj.2017.100201.

10. Labas, I., Darabos, E., \& Nagy Tunde, O. (2016). Competitiveness - Higher Education [Electronic version]. Studia Universitatis ,, Vasile Goldis” Arad-Economics Series, Vol. 25(1), 11-25. DOI: 10.1515/ sues-2016-0002 .

11. Mainardes, E., Ferreira, J., \& Tontini, G. (2011). Creating a Competitive Advantage in Higher Education Institutions: Proposal and Test of a Conceptual Model [Electronic version]. International Journal of Management in Education, Vol. 5(2/3), 145-168. DOI: 10.1504/IJMIE.2011.039482.

12. Matkó, A., \& Szücs, E. (2012). The Strategic Management Tools and their Relation to Competitiveness in Higher Education [Electronic version]. Annals of the Oradea University. Fascicle of Management and Technological Engineering., Vol. XXI (XI)(2), 1-7. DOI: 10.15660/AUOFMTE.2012-2.2664.

13. Nguyen, H., Pattinson, S., \& Scott, J. (2016). Managing Knowledge for Innovation to Gain Competitiveness. 4th International Conference on Innovation and Entrepreneurship (pp. 191-197). Toronto: Academic Conferences and Publishing International Limited.

14. PRISMA Flow Diagram. (2018, January). Retrieved Februay 1, 2018, from: PRISMA: http://www.prismastatement.org/PRISMAStatement/Default.aspx.

15. Soliman, M., \& Karia, N. (2015). Higher Education Competitive Advantage: Enterprise Resource Planning Systems [Electronic version]. International Journal of Research in Management \& Technology, Vol. 5(5), 380-384. DOI: 10.15660/AUOFMTE.2012-2.2664. 